\title{
The Relativity Strategy of Old Javanese
}

\author{
Ni Ketut Ratna Erawati \\ Faculty of Arts, Udayana University, Bali, Indonesia
}

\begin{abstract}
Old Javanese is one of the temporal dialects in Indonesia that is estimated to develop from the IXXV century. The language has a lot of langues inherited in the form of literature kakawin (Old Javanese poetry) and the form of parwa (Old Javanese language prose) until now. Literary works in the form kakawin and parwa are very popular work to be sung in Balinese society especially in religious ceremonies. Therefore, the Old Javanese is very worthy of being used as a linguistic study even though the language is categorized as a dead language. In morphological typology, Old Javanese is an agglutinative type. On the other hand, syntactically the Old Javanese language includes the Split-S typology. Associated with morphological typology and syntax, the Old Javanese has a core system or verb. Thus, the Old Javanese has various forms of verbalternation in clause structures, either in single clauses or complex clauses. Relative clauses are one part of the complex clause having a change of grammatical relation when the insertion of certain linguistic elements. The topic of this study was the relativity strategy in Old Javanese. The relativity strategy of Old Javanese was described with related theories and concepts. Based on the result the Old Javanese could make the subject to be relative by inserting element of the relative sang and ikang. On the other hand there was also an indirect relativity by marking of verbs and penloping.
\end{abstract}

Index Terms-grammatical structure, argument structure, strategy, relativization

\section{INTRODUCTION}

Old Javanese is one of the Austronesia languages. The Old Javanese is one of the temporal dialects thought have developed from the IX - XV century. Historically, the language has a very rapid development during the reign of King Maharaja Dharmawangsa Teguh in Majapahit Kingdom era. Old Javanese began to be abandoned by its speakers since the entry of Moslem into Indonesia with its Arabic. Since then the Old Javanese has divergence and evolved into two different languages, namely the Central Java language and the Modern Java language (see Uhlenbeck, 1964, Zoetmulder, 1985).

The ability of the written traditions possessed by the community at that time made the Old Javanese language documentable so that it could be inherited until now. The language documentation can be used as a field of language, literature, and philology research. Currently the Old Javanese is categorized as a dead language. The language can only be learned and understood through written relics. As Ferdinand de Saussure (1916) statement that langue is concrete since it is a collectively agreed sign of language and is a social fact so that it can be understood (Hidayat, 1996, p. 9).

In morphological typology, Old Javanese belongs to the agglutinative type. Agglutination typology has a very complicated word-forming procedure. Agglutinative language has characteristics, namely (1) a word can be formed from two or more morphemes that clearly morpheme boundaries; (2) each morpheme does not change in form so that it can be directly identified (see Comrie, 1989, Keraf, 1990). Regarding with the typological of the language, then in the formation of a word, a basic verb can be formed into a derived form formed through a morpheme process. The grammatical process can be a combination of bound morphemes, such as affixation with free-form, pre-categorical forms, or any other combination of words. Thus, a derivation can be clearly seen in its morpheme boundaries. Any changes in form and meaning may result in a syntactic relation change when the verb is used in forming clauses. For example, an intransitive clause can be formed into a transitive clause; a monotransitive clause can be formed into a bipolar clause. The same thing can be seen in the form of verbs, the number of core arguments required, as well as changes in functional relations in the clause. Thus, the change in verb form greatly implies the clause structure of either a single clause or a complex clause.

From a syntactic point of view, Old Javanese includes Split-S typology that treats part of S equal to A (Sa) and part S is treated in the same way as $\mathrm{P}(\mathrm{Sp})$ (Erawati, 2014). The determination of the typology is based on a change in grammatical relations within the basic clause structure in the derived clause. The combination of two single clauses can cause syntactic functions in complex sentences often share arguments. The thing usually appears in clauses with a control structure. The function of subject or any hidden grammatical object function (covert). Thus, the elements of disappearance in the complex clause are very numerous. For that purpose, it is explained first about the basic structure and structure of argument in Old Javanese followed by a complex sentence.

Universally, the basic structure and structure of the argument in the Old Javanese clause, ie the intransitive predicate $(\mathrm{S})$, intransitive extension $(\mathrm{S}, \mathrm{E})$; Transitive predicate $(\mathrm{S}, \mathrm{O})$, transitive expansion predicate $(\mathrm{S}, \mathrm{O}, \mathrm{E})$, copulate clause, and verbless clause. The classification of the clause was adapted from Dixon (2010, p. 161). The intransitive clause has only the core argument as a grammatical subject. Intransitive expansion clauses have additional elements required by verbs. A clause with a transitive predicate has two core arguments as the subject NP and NP of the grammatical object. 
Transitive expansion clauses require three core arguments, namely subject, object, and additional elements. The additional element in Old Javanese can be E (NP; Sentence). Copulation clauses can add copula elements as a predicate.

In relation to the division of clauses above, Old Javanese has a very varied clause structure ranging from the simplest to the very complex structures. Complex sentences have a very wide range, such as the study of inter-clause. Theoretically, a complex sentence consists of four types, namely (1) a sentence has a relative clause, (2) a purposive clause / sentence aim, (3) a complement clause, and (4) a clause with a raising construct. The discussion of complex sentences actually aims to determine the role of morphosyntax typologically that forms the complex sentence. Based on the above description, this article is only discussing about the relativity of complex clauses in Old Javanese. There were two questions as the problems of study, namely (1) what elements can relativize the grammatical functions in the Old Javanese; and (2) how is the strategy of relativity in Old Javanese? The aim of this research was to describe and explain the syntactic elements in the clause grammatically. The problems were analyzed by applying the concepts and theories that match the object of the study. Theories and concepts are described in the following sub-sections.

\section{THEORY AND CONCEPT}

Grammatical relations are terms used in relational grammar. The theory of relational grammar was originally developed by Perlmuter and Postal in the early 1970s. Grammatical relations are defined as primitives. Blake (1994) introduces three types of purely syntactic grammatical relationships, namely subject (S), direct object (DO), and indirect object (IO). In addition, semantic relationships, such as locative, benefactive, and instrumental are collectively referred as oblique relations (p. 76). Syntactic relations are considered to form a hierarchy by giving 1, 2, 3 numbering which is used to indicate the corresponding relation as shown below:

S DO IO OBL

12

The hierarchy can be seen in the following example (taken from Blake, (1994, p. 76).

Eva gave the apple to Adam

123

The example implies that 1 is the subject (agent), 2 is the direct object (theme), 3 is the indirect object (benefactive). Therefore, the nature of grammatical relations can be understood through the interaction of semantic roles and pragmatic relations. For example, subjectivity can be understood by subject prototypes as agent and topic interactions. The clause structure above has different grammatical relations at different levels. For example, a grammatical relationship may change from active structure to passive derivative structure which indicates a change of subject relation. That formation structure depends on the perspective of the speakers of the language. Those grammatical relationships are reference for describing the various aspects of clause structures and the principles of the universe that govern the structure and organization of natural language syntax. Based on the description of the theory, the alternation of verbs in predicate can result in the change of syntactic relations.

\section{A. Sentences and Clauses}

Alwi, et al (2000) argues that a clause is a syntactic unit consisting of two or more words containing predictive elements (p. 312--313). He further said that the sentence is no different from the clause. The thing that distinguishes the sentence and clause is a sentence has the final intonation or punctuation while the clause has no final intonation or punctuation. Both sentences and clauses are syntactical construction which containing predication elements. Viewed from the internal structure, both sentence and clause consist of predicate element and subject with or without object, complement, or description. The definition of the basic structure of a clause can be derived from the basic structure of the sentence. Sentences have more complex features than clauses. This can be interpreted as not all sentences can be called clauses.

As described above the things that distinguish between a clause and a sentence is either the final intonation or the reading sign. However, in this paper the sentences and clauses in are not distinguished. The basic clause is a clause construction that has at least the characteristics, namely (1) consists of one clause, (2) the elements are complete, (3) the order of its elements in the most common order, and (4) does not consist of question or denial (Alwi, et al, 2000, p. 319). Thus, it can be said that the basic clause can be interpreted as a single declarative sentence consisting of common elements. To clarify clauses it is necessary to understand the problem of syntactic functions, the syntactic categories, and the semantic role of elements that fill the clause's constructions. Referring to the above concept, judging from the element/category of words that populate the predicate, clauses in Old Javanese are differentiated into predicated verbal and copulate clauses. Verbal predicated clauses can be classified into intransitive verb types, intransitive extensions, transitive, transitive extensions. Meanwhile, the Old Javanese copula clause can be filled by copula verbs and without verbs (Dixon, 2010).

\section{B. Complex Sentences}

Simple sentences can bound other simple sentences to form more complex constructs (sentences). Sentences formed from the combination of these clauses become complex sentences (complex sentence). The relationship between clauses in compound sentences is quite diverse and complicated. The complexity is caused by the interaction of three different 
parameters, namely the internal arrangement of the clauses, the structural relations of the clauses, and the semantic relation of the clauses (see Elson and Pickett, 1983, p. 120).

Other experts, Kuiper and Allan (1996) argue that a sentence that has an embedded clause (subordinate clause) is called a complex sentence (p. 264). Van Valin Jr. and LaPolla (2002) argue that there are two fundamental questions that every theory has to answer about complex sentences, namely (1) what units are involved in that complex sentence? (2) What are the relationships exist between the units in the construction? Van Valin Jr. and LaPolla found the answer (1) derived from a clustered structure of clauses, the boundaries of the basic complex sentence formers are the basic core of the clause. Meanwhile, for answer (2) is a complex sentence divided into two, i.e. a sentence whose elements are grammatically equivalent (coordinate) associated with a coordinated conjunction and a clause whose elements are unequal (subordinate) connected with a subordinate conjunction (p. 441-443). In Indonesian, for example, the coordinating conjunctor is dan 'and', tetapi 'but', and etc. The subordinate conjunctor, such as untuk 'for', supayal agar 'in order', jika 'if', and so on, and so forth corresponds to the purpose of combining the clause (Alwi, et al, 2000, p. 296-302).

In relation to complex sentences, Artawa (1998) argues that not all languages treat syntactic constructs in the same way. Treatment is highly depending on the type of concerned language. In the accusative languages A (gent) and S (ubject) are characterized by a number of features, such as case, control, verb match, word order, and A / S are usually not expressed with unlimited verb forms. Meanwhile, in syntactically ergative languages, the relationship of $\mathrm{P}($ atient $)$ and S(ubject) play an important role in a number of grammatical processes (p. 83). For example, only $\mathrm{P}$ and $\mathrm{S}$ can be relativized. $\mathrm{P}$ and $\mathrm{S}$ still appear with unlimited forms of verbs. Furthermore, in accusative language, S/A construction is described as the carrier of the subject relation. In ergative language, $\mathrm{S}$ and $\mathrm{P}$ are treated equally morphologically; the question that arises is whether $\mathrm{S}$ and $\mathrm{P}$ are defined as bearers of subject relations? The thing to be remembered is the difference between morphologically ergative language and syntactically ergative language.

Anderson in Li (ed.) (1976) argues that most ergative languages morphologically have no ergative syntax. Syntactic process in this language is like a syntactic process in the accusative language. The combination of $\mathrm{S}$ and $\mathrm{P}$ in ergative language is often referred to be absolute. Meanwhile, $\mathrm{A}$ in a transitive clause and in this type of language is said to bring ergative relation. As discussed in the sub-section of the structure of argument and grammatical relation of Old Javanese especially on the subject, Old Javanese language approaches accusative language characteristic, but it needs to be discussed and further proved in the grammatical association concerning the relation of syntactic functions.

\section{The Relativity Strategy of Cross-languages}

Every language has a grammatical strategy in terms of relativisation. There is a language that can only relativize $\mathrm{S}$ (ubject), there is also a language that can only relativise $\mathrm{P}$ (atient). To obtain the position availability of the nominal phrase structure argument for the formation of relative clauses, the study is based on the grammatical relational hierarchy approach, accessibility hierarchy proposed by Keenan and Comrie (1977). Keenan and Comrie (see also Artawa, 1998, p. 83), Aboh, (2010, p. 99) suggest the following hierarchy and in this case the peak position is more universally achievable for relativization.

Hierarchy of Achievement (HA)

Subject (SUBJ)> Direct Object (DO)> Indirect Object $(\mathrm{IO})>$ Oblique $(\mathrm{OBL})>$ Genitive $(\mathrm{GEN})>$ Object comparison (O-COMP).

The hierarchy sets the ease to achieve in the relative clauses formation. If an FN can be achieved for relativity in a language then all higher FNs in the hierarchy can also reach the relay. Keenan and Comrie (1977) also include NPs that are not directly related to verbs, such as the possessor of subject into the hierarchy. Further, there is a set of hierarchical constraints with respect to the hierarchy of attainment. The constraints are (1) a language must be able to relativised the subject; (2) any establishing a relative clause must apply to the continuing segment of the achievement hierarchy; and (3) the strategy that apply to a single grain of hierarchy of achievement should basically not apply to a lower item.

Kalkutungu language is one of the only languages that relativies the absolute. Examples is shown below (from Blake, (1994) and adapted by Artawa (1998, p. 84-85).

(1) Ngulurrmayi-nha ngga-thu yurru [ ] ngartathati-nyiu

Catch my PAST-ERG people-NOM sit-PART

'I caught the man [once he was sitting]

(2) Ngulurrmayi-nha nga-thu yurru [ ] thuku-yu itya-nyin

Catch -PAST I-ERG people- NOM dog -ERG bites-PART

'I caught the man [as soon as he] was being bitten by a dog'

In example (1) the function that relativised in the subordinate clause is $\mathrm{S}$ which is not disclosed and indicated [ ]. In the datum (2) the function $\mathrm{P}$ is relativised and $\mathrm{P}$ is not being expressed in the subordinate clause. If each role is not commonly marked as absolute it is relegated then derivative construction must be used. To say 'I catch the person while he is biting the dog' the subordinate clause must be transitive. In this case, agent typically marked as A is now expressed as absolute relations and $\mathrm{P}$ is interpreted as dative. It can be seen as follows.

(3) Ngulurrmayi-nha nga-thu yurru [ ] thuku-u itya-yi-nyin

Catch-PAST I-ERG people NOM dog-DAT bite-AP-PART

'I caught the man [while he was] being bitten by a dog' 
In Balinese, Artawa (1998: 85-88) argues that only subject can be relativised. Here are the examples and explanations.

(4) Emeng-e gugut cicing

Cat-DEF bite dog

'The Dog bit the cat'

(5) Emeng-e [ane gugut cicing] gelem

Cat-DEF [REL bite dog] ill

The cat [which bit the dog] is sick'

(6) * Cicing [ane emeng-e gugut] galak

Dog [REL-cat-DEF bite] fierce

'The dog [which bit the cat] is fierce'

At (4) the basic verb construction, NP before verb is patient and NP post verb is an agent. Relative clause at (5) shows that the patient can be relativised. Meanwhile, agent can not be relativised as in example (6). The relativity confirms that NP on (4) is the grammatical subject of the clause. Compliment of the agent (cicing) is not achieved for relativity. The relative NP is clearly in Balinese. According to Artawa (1998, p. 85-86), since zero construction agent did not go well for relativity, Balinese lacked ways to reveal information such as 'Dogs that bite the cat is fierce' (see 6). However, it can be found that agents in Balinese can be relativised 'indirectly' by using 'diathesis derivative' strategy. Diathesis is a common practice for relative in a language.

According to Givon (1990, p. 669-670), there are various strategies in forming relative construction by cross language. One of these is the 'verb-coding strategies', namely the relativity strategy which is the interaction between the relativity and the rules of promotion. Promotional rules, also called substitutions, in Balinese are addressed by nasal prefixes in verbs. The verb marking strategy as the relativity strategy in Balinese can be seen as follows (see Artawa, 1998, p. 86).

(7) Emeng-e gugut cicing.

Cat-DEF bite dog

'The dog bit the cat'

(8) Cicing-e ngugut emeng-e [N-gugut]

Dog-DEF ACT-bite cat-DEF

'The dog bit the cat'

(9) Cicing-e [ane ngugut emeng-e] galak

Dog-DEF [REL ACT-bite cat-DEF] fierce

'The Dog which bit the cat is fierce'

Furthermore, Artawa (1998) explains that in (8) the agent compliment (cicing) is expressed as the subject. The subject can be relativised as in data (9). Based on the comparison $(4,5,6)$ that in Balinese can only relativiting subject (p. 86). The cross-language relativity strategy found by the experts might be used as a reference to identity the relativity in Old Javanese.

\section{METHODOLOGY}

An article would be appropriate and systematic if the application of methods and techniques are proper. Therefore, this article was based on three stages of methods and techniques, namely methods and techniques of providing data, methods and techniques of data analysis, and methods and techniques of presenting the results of data analysis. The methods and techniques of data providing was observation. The term of observation here was listening in spoken language and reading in written language. Note taking technique was used when researchers deal with the use of textual languages, for example: ancient texts, narrative texts, languages in mass media, and others (Mahsun, 2005, Bungin, 2001, Moleong, 2000, Creswell, 2009). Associated with the methods and techniques of providing data, then the data was in written form which the ancient Javanese text as the primary data. The data from other researches were used as the secondary data to complete the primary data. For data refinement assisted by note taking, record, and translation techniques.

The next was the method and technique of analyzing data. There were two methods in analyzing data, namely the intralingual comparing method and extra lingual comparing method. The concept of comparing is to compare something or something that is compared must contain the meaning of interconnection while intralingual refers to the elements that are in language (lingual). The intralingual comparing method is an analytical method applied by comparing lingual elements, both in one language and in several different languages. The extra lingual comparing method is comparing the elements from outside language. As a concrete step, it was completed by the technique of applying connecting-comparing-equal technique, connecting-comparing-differentiate technique, and connectingcomparing-equal the core. (Mahsun, 2005, p. 111-113, c.f. Djajasudarma (1993), Sudaryanto (1993) .In this analytical stage, the rules governing the existence of the object of research must be formulated. The rules that are found even in the simplest results are at the gist of a scientific activity.

At the final stage, methods and techniques of presenting the results of data analysis was used. The results were described in two ways, namely (a) formulation or description using ordinary words, including the use of technical terminology with the aim to obtain straightforward results. (B) The formulation by means of certain signs, abbreviations, 
tables or symbols constituting a convention in the research process. Both methods were used in a coherent way to obtain a maximal presentation. Both methods are commonly referred to as informal and formal methods.

\section{DISCUSSION}

\section{A. Structure of Old Javanese Clauses}

In morphological typology, Old Javanese is classified into agglutinative typology. Agglutinative language has a variety of morphemes as word-forming. The characteristics of agglutinative language, namely: (1) Agglutination language consists of morphemes combination and morphs; (2) One word can be formed from many morphemes that morphemes boundaries in words are very clear and always have variants so they are easily to be identified directly; (3) The basic form is always affixed with affixes that usually have functions and meanings; and (4) Using affixes to refer to a grammatical category (Comrie, 1989, c. f. Keraf, 1990). For example, the verb gawe 'work' can have a derived form, such as agawe, magawe, gumawe, ginawe, and etc. The forms of the verb as the core of the clause have various perspectives from the speaker. If the speaker wants to put forward the patient / theme then the chosen verb is ginawe, and if the speaker wants to put forward the agent then the selected verb is agawe, magawe, or gumawe. Theoretically, the classification of the Old Javanese clauses was referred by Dixon (2010). Thus, in general, the structure of the Old Javanese clause is classified into a verbless clause (verbless), clause with verbs, and copula clause. When associated with syntactic typology, the Old Javanese includes the Split-S typology, meaning treating S as equal to A (Sa) and in other one side treating $\mathrm{S}$ equal to $\mathrm{P}(\mathrm{Sp}) . \mathrm{S}$ is the subject of the intransitive clause, $\mathrm{A}$ is the subject of the transitive clause, and P / O is the object of the transitive clause. (See Erawati, 2014).

Regarding to morphological and syntactical typology, Old Javanese has many verb alternations within its clauses. For example, verbs in basic form (zero constructs) that predicate the basic clauses of Old Javanese are largely appearing in intransitive construction and imperative constructions. Meanwhile, in transitive construction, the verbs that appear are always in the form of a derived verb through affixation. The statement can be seen the following data.

(1) Lungha ta sira Go PART 3 SG 'His gone'

(2) Ma-lungha ta sireng alas ACT-go PART 3SG-PREP Forest 'He goes to forest'

(3) Dateng ta kawitan-ira kabeh,...

Come PART ancestor-POSS-3 all,

'Come to all his ancestors'

(4) alap pangana(ng) $k u$ (imperative)

Take food-1SG

'Take my food'

(5) Naga Taksaka s-um-ahut Maharaja Pariksit. Name ACT-bite name 'Naga Taksaka bit Maharaja Pariksit.

(6) Ksamakna nghulun um-aradhana sangyang. Forgive 1SG ACT-call ART 'Forgive! I called the master'

(7) Anugraha-ngkw-i kitãnak-a satus. Anugraha-1SG-BEN 2SG-anak-IR one hundred

'I will grant you a hundred children'

(8) Dadi ta sira wuta, tar panon desa

So PART 3SG blind, NEG view village

'Be blind, see no village'

The clauses (1), (2), (3), (4) are intransitive clauses. The data (1) shows the form of the verb lungha'pergi ', the datum (2) malungha' go ', datum (3) datang 'come', datum '(4) verb alap 'take', the intransitive verbs, there are free basic and derived form. Basic verbs may occupy predicate functions in clause structures. The lungha form in the datum (1) can also be pronounced with the prefix $a$ - or $m a$ - as in datum (2) but remains as an intransitive verb. The difference between the basic verb and the intransitive derived verbs lies in the presence of an additional element as an OBL relation. Basic verbs may also appear in imperative clause structures, as in datum (4). The verb alap can be marked by other suffixes, such as $m a-$, ang-, -um-, -um-/- $i$, or affixed combinations as transitive active markers.

Furthermore, in data (5), (6), (7) are transitive clauses and the verbs are amplified by affixation. The verbs sumahut 'bite' and the verb umaradhana 'summon' are both morphologically grounded with -um-. Affix -um- in Old Javanese is an active marker that is contrasted with affix -in- as the passive marker. In addition to -um-, the verb is still possible with other affixes. The verb anugraha 'bless' is a verb attached to the enclosure - $(n g) k u$ and the suffix $-i$, so as to form anugrahangkwi 'I blessed', The basic form of anugraha can be attached by other affixes, such as in manganugrahakên, kanugrahan, anugrahi, Construction $(5,6)$ are pure transitive construction $(\mathrm{S}$ and $\mathrm{O})$, while at $(7)$ is a transitive 
expansion construct (S, O, and E) .Finally, the datum (8) is a clause construction with copula. In Old Javanese, such constructions can be derived from non-verbal clauses, which the predicates are filled by nominal, adjectival, numeral, and adverbial categories. Based on the transitive clause structure, the strategy relativity are particularly vulnerable in Old Javanese.

\section{B. Elements and Relativity Strategies in Old Javanese}

Every language has elements as a relative in the clause. However, the element of relativity is not in the same position. There are languages that only relativize the function of the subject and some only relate the function of the object. An adaptive language uses a morphological tool and some use elements that are free. In fact, there are languages that have no devices or relativity tools. Related to the topic, Old Javanese has many linguistic elements that seem ambiguous. On the other hand, a linguistic form can have certain syntactic functions, and in one side the same linguistic form can function as relativity. For example, the element 'sang', lexically is an article category that usually refers to a person's name or position, and one side, the form of the 'sang' is an element of relativity. Therefore, the differences in those functions need to be proven its existence in the clause. Based on the Old Javanese morpheme system, morphological markers tend to exist. There are several possibilities of the relativity strategy of Old Javanese described as follows.

\section{Subject Relativity}

The basic structure of clause and arguments of Old Javanese is as the basis for discussing the relativity strategy in their clauses. The insertion elements in the clause are important to be discussed in order to identify grammatical functions and elements in the clause structure. The complex sentence in Old Javanese is generally composed of two or more basic clauses. Thus, to find out the strategy of relativity in Old Javanese can be seen in the following transitive clauses.

(9a) Apan tan matīkang Naga Taksaka [ikang] s-um-ahut

$$
\begin{aligned}
& \text { Because NEG die-DEF name [REL ] sira Maharaja Pariksit } \\
& \text { wwang atuha-nira old } \\
& \text { man old POSS3SG 3SG ART name, } \\
& \text { tuhun ikang naga sama-nya pějah, } \\
& \text { although DEF dragon all-POSS3SG dead } \\
& \text { t-um-iba ring kunda } \\
& \text { ACT-fall PREP stove }
\end{aligned}
$$
cult stove'

'Because the Naga Taksaka which bites his parents does not die, even though the snakes mostly die, it falls into a

(9b) Apan tan matikang NagaTaksaka s-um-ahut wwang atuha-nira

Because NEG die-DEF name ACT-bite man old-POSS3SG

sira maharaja Pariksit, tuhun ikang naga samanya pêjah,

3SG ART name was DEF dragon all-POSS3SG dead,

t-um-iba ring kunda

ACT-fall PREP stove of worship stove'

'Because Naga Taksaka bit off his parents does not die, even though the snakes mostly die, fell into the cult

(10a) [Ikang] desa kulwan Sanghyang Eka Dasa Rudra r-um-aksa,

REL village west ART name ACT-keep

Kapwãsangkĕp ing sarwãstra. [ã: a-a]

Supposedly-complete PREP of all-arms

'Sanghyang Ekadasa Rudra who keeps the west region is completed by all weapons'

(10b) Desa kulwan Sanghyang Eka Dasa Rudra r-um-aksa,

Village west ART name ACT-guard

kapwãsangkêp ing sarwãstra. [sarwa-astra]

Complete PREP all-weapons

'Sanghyang Ekadasa Rudra keeps the west region is completed by all weapons'

(11a) Yapwan [ikang] lor village, sanghyang Dwadasaditya r-um-aksa,
If REL village north
ART name
ACT-keep

makadi sanghyang Indra,....

like ART name

'Although Sanghyang Dwadasaditya who keeps the north regions, like the god Indra'.

(11b) Yapwan desa lor sanghyang Dwadasaditya r-um-aksa, makadi sanghyang Indra.

'Although village north ART name ACT-keep like ART name

'Although Sanghyang Dwadasaditya keeps the north regions, like the god Indra'

(12a) Ma-takwan ta sireng mantri, [sira-ing]

ACT-ask PART 3SG-PREP minister

[Ikang] t-um-on Bhagawan Kasyapa,

REL ACT-see name 
'He asks to his minister who sees Bhagawan Kasyapa'

(12b) Ma-takwan ta sireng mantri, [sira-ing]

ACT-ask PART 3SG-PREP minister

t-um-on Bhagawan Kasyapa, [-um- : ton]

ACT-see ART the name

'He asks to his minister, see Bhagawan Kasyapa'

(13a) Sirata s-in-omah de haji [sang] ma-gawe yajna sarpa .

3SG PART PASS-wife PART king REL ACT-make sacrifice snake

'She is married by the king who makes the snake as sacrifice of the serpent'

(13b) Sira ta s-in-omah de haji ma-gawe yajna sarpa,...

3SG PART PASS-wife PART king PREP-ACT-make sacrifice snake

'She is married by the king to make the snake as sacrifice of the serpent'

All of the above clauses, ie (9a), (10a), (11a), (12a), (13a) are relative clauses. The sentence in the datum (9a) is an intransitive-transitive combined clause. In the data, the transitive verb sumahut has two core arguments, as subject and object. Naga Taksaka is a grammatical subject, wwang atuha nira sira maharaja Pariksit is the object of that sentence. The grammatical subject is relativized to the ikang form and can be inserted between the grammatical subject and the predicate verb in the sentence. If the clause is returned to its basic / or is not be relativitized it becames ( $9 \mathrm{~b}$ ). Thus, subjects in Old Javanese can be relativized by inserting the ikang form between the subject FN and its verbs.

Datum (10a) is also a relative clause. The form of relativity is characterized by the form ikang which is at the beginning of the sentence. In the data, Sanghyang Eka Dasa Rudra is the grammatical subject of the sentence; the Desa Kulwan 'village/western region' is the object. The other constituents that appear in the transitive sentence are complementary. The grammatical subject of the rumaksa verb 'keep' in (8a) can be relativized by inserting ikang element. When the ikang element is deleted, it likes datum (10b). The same thing is data (11a and 11b). Meanwhile, datum (12a) has a combination clause, that the first clause is intransitive; the next clause is transitive clause. When the transitive sentence construction is observed, there is a verb tumon 'see' verb which requires two core arguments that serve as subject and object. The grammatical subject of the sentence is the mantri 'minister', which shares the argument with an intransitive clause in front of it. Meanwhile, Bhagawan Kasyapa is the object the sentence. In the sentence there is an element of relativity which expressed by elements 'ikang'. The form of ikang can be directly placed after grammatical subject without any structural decline. If the element of relativity is deleted, it would look like (12b). Thus, subjects in Old Javanese can be relativized by the ikang element.

Finally, in the data (13a) there are two transitive clauses. The first clause is manifested in passive form; however, the relativity strategy in data can be seen in the next sentence. The agent of both sentences is the haji 'king' (oblique of the first clause agent as well as the second clause agent). The element of the relativity sentence is characterized by the form of sang (which can be interpreted 'that', but on the other hand sang is article. The grammatical subject of the haji 'king' can be relativized by the inserting sang element. When the element is deleted, it looks like at (13b). Based on these data, the relativity in Old Javanese can be done by inserting the form of ikang element, and sang the ' that or which' without any structural revaluation. Thus, subjects in Old Javanese can be directly relatable (a and b are grammatical). Other examples are shown in the following interrogative form.

(14) Aparan [ikang] wwang l-um-ěbw-akĕn ing sumur $i$ kita?

INTR REL man ACT-entrance-CAUS PREP well PREP 2SG

'Who is the one who thrusts you into the well?'

\section{Objects Relativity}

Previously has been explained about the strategies to relativize the subject in Old Javanese. Further, it would be explained grammatical strategy relating objects in Old Javanese. The object relativity in Old Javanese is done indirectly by using 'diathesis derivative', as proposed by Givon (1990, p. 669-670). Old Javanese includes a language that has many alternate verbs. Thus, the relativity in Old Javanese is one of languages that has verb marking strategy in terms of relativity. Grammatical strategy is characterized by the interaction between relativity with promotional rules (the object becomes a subject, passive, or with construction topicalization). See the following sample data.

(15) T-um-inghal ta Dewi Kunti ri $\quad$ Sang Karna,
ACT-see PART name $\quad$ PREP ART name
ma-tutur ta sira ry anak-nira ri Sanghyang Aditya
ACT-word PART 3SG PREP child-POSS3SG PREP ART name
Ikang h-in-añut-nireng
REL PASS-float POSS3SG-PREP place ago

'Dewi Kunti sees to Sang Karna, she says about his son from Sanghyang Aditya whom swept away in Gangga river ago'
(16) Sira ta ma-wěka the Yadukula, [ikang]
SEG ACT-child ART name REL
s-in-angguh
watěk Yadu.
'She is the family of Yadu who is supposed as Yadu group' 
In the datum (15) the verb hinañut 'swept away' has an active form humañut, angañut 'sweeps away'. If the sentence is returned to its active diathesis, it looks like Sira angañutakĕn anak nira ri sanghyang Aditya ing Gangga nguni 'She washed away her son with Sanghyang Aditya in the river Gangga ago'. The active sentence object is promoted to be grammatical subject of the passive sentence which marked in the verb with the infix -in-. After becoming a derivative diathesis, it can be relativized by inserting an ikang form. The same thing may apply to (16). Based on these data, the Old Javanese can also relativize the object through derivative construction or topicalization.

Another example is the relativized object.

(17) [Ikang] naga anak atuha de sang Kadru,

REL dragon child eldest PREP ART name

Am- $(p)$ rih ta yãgawe tapa sira, [ya-a-gawe]

ACT-need PART 3SG-create concern 3SG

ang-aradhana bhatara Brahmãng-anugraha ta sira

ACT-call god name gift-IR PART 3SG

'The dragon of Sang Kadru who is the eldest, he wants to meditate, worship the God Brahma, he blessed'

(18) Kunang [ikang] antiga kari sa-siki p-in-ahayu

It is said REL eggs live NUM PAS-grown item

K-in-ayatna-kěn de Sang Winata [-in-/-akên-kayatna]

PAS-hearted PREP ART name

'A live egg is carefully preserved by Sang Winata'

Based on the examples (15), 16, 17, and (18), the idea of relativizing objects in Old Javanese is done through derivative construction or topicalization, i.e. passive diathesis with markings in the verb. Passive verbs in Old Javanese are characterized by a infix -in- and prefix $k a$-. Based on the analysis it can be said that the Old Javanese has the elements of ikang and sang. In terms of relativizing grammatical subject can be achieved directly, while in relativizing the grammatical object must be through derivative construction. Thus, the subject's relativity can be achieved directly by inserting the relativity elements. Meanwhile, the relative object is marked on the verb. Meanwhile, the object relativity must be through the derivative / parsing construction (indirect). In other words, only the subject can be directly relatable.

\section{CONCLUSION}

Based on the analysis it can be concluded that the relativity in Old Javanese is constituted by the basic structure of the clause. In relation to the relative clauses of Old Javanese can be found things like the following.

(1) Elements of relativity in Old Javanese, are ikang and sang elements.

(2) The elements of sang and ikang can be directly inserted between grammatical subjects and verbs without any decrease in grammatical structure. Thus, the subject can be relativized by inserting the interrupted elements of $i k a n g$, and sang directly.

(3) Grammatical objects can be relativized by marking on verbs through derivation constructs with passive diathesis and topicalization strategy. Universally, the passive structure of the Old Javanese is morphologically observed with the infix -in-.

\section{Recommendation}

The complex clause structure in Old Javanese that is still related to this article requires to be studied further. The aim is to obtain a more comprehensive and deeper understanding about Old Javanese. Therefore, other researchers are suggested to contribute to the development of linguistic and ancient Javanese texts.

\section{REFERENCES}

[1] Aboh, E. O. dan James Essegbey. (2010). Topics in Kwa Syntax. London: Springer Dordrecht Heidelberg

[2] Alwi, Hasan, Soenjono Dardjowidjojo, Han Lapoliwa, dan Anton M. Moeliono. (2000). Tata Bahasa Baku Bahasa Indonesia. Jakarta: Balai Pustaka.

[3] Artawa, Ketut. (1998). "Ergativity and Balinese Syntax". Dalam NUSA Studies of Indonesian and Other Languages in Indonesia. vol. 42-44. Jakarta: Pusat Kajian Bahasa dan Budaya.

[4] Blake, Barry J. (1990). Relational Grammar. New York: Routledge.

[5] Blake, Barry J. (1994). Case. Cambridge: Cambridge University Press.

[6] Bungin, Burhan. (2001). Metodologi Penelitian Sosial. Surabaya: Erlangga University Press.

[7] Comrie, Bernand. (1989). Language Universal Linguistik Typology: Syntax and Morphology. Oxford: Basil Blackwell.

[8] Creswell, John W. (2009). Research Design: Qualitative, Quantitative, and Mixed Methods Approaches. Los Angeles, London, New Delhi, Singapore: SAGE.

[9] Dixon, R. M. W. (2010). Basic Linguistic Theory: Grammatical topics. Volume 2. New York: Oxford University Press.

[10] Djajasudarma, F. (1993). Metode Linguistik Ancangan Metode Penelitian dan Kajian. Bandung: PT. ERESCO.

[11] Elson, B. F. and Velma Pickett. (1983). Beginning Morphology and Syntax. Texas: Summer Institute of Linguistics.

[12] Erawati, Ni Ketut Ratna. (2014). 'Valensi dalam Bahasa Jawa Kuna: Suatu Kajian Morfosintaksis' Disertation on Postgraduate Program Udayana University. 
[13] Givon, T. (1990). A Syntax, A Functional Typological. Volume II. John Benjamin Publishing Company, Amsterdam/Philadelpia.

[14] Hidayat, Rahayu S. (1996). Pengantar Linguistik Umum. (Edisi terjemahan dari judul asli Cours de Linguistique Generale oleh Ferdinand de Saussure). Yogyakarta: Gadjah Mada University Press.

[15] Keenan, E. L. and Comrie, B. (1977). "Noun Phrase Accessibility and Univesal Grammar”. Linguistic Incuiry 8. Hal: 63-99.

[16] Keraf, Gorys. (1990). Linguistik Bandingan Tipologis. Jakarta: Gramedia.

[17] Kuiper, K. and Allan, W. S. (1996). An Introduction to English Language. London: Macmillan Press Ltd.

[18] Li, Charles N.(ed.) (1976). Subject and Topic: New York: Academic Press, Inc.

[19] Mahsun. (2005). Metode Penelitian Bahasa: Tahapan Strategi, Metode, dan Tekniknya. Jakarta: PT Raja Grapindo Persada.

[20] Moleong, Lexy. (2000). Metode Penelitian Kualitatif. Bandung: PT Remaja Rosdakarya.

[21] Sudaryanto. (1993). Metode dan Aneka Teknik Analisis Bahasa. Yogyakarta: Duta wacana University Press.

[22] Uhlenbeck, E. M. (1964). A Critical Survey of Studies on the Languages of Jawa and Madura. Martinus Nijhoff: 'sGravenhage.

[23] Van Vallin, Jr. Robert D. dan Randy J. Lapolla. (2002). Syntax: Structure, Meaning and Function. United Kingdom: Cambridge University Press.

[24] Zoetmulder, P.J. (1985). Kalangwan: Sastra Jawa Kuno Selayang Pandang. (edisi terjemahan oleh Dick Hartoko S. J.). Jakarta: Djambatan. Cetakan II.

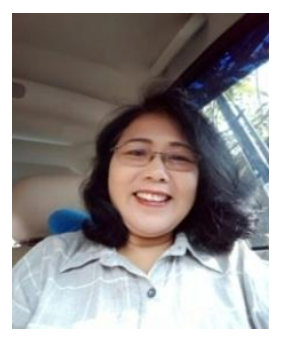

Ni Ketut Ratna Erawati was born in Gianyar, Bali, Indonesia on March $7^{\text {th }} 1965$. She received her Dr. degree in linguistics from Udayana University, Bali, Indonesia in 2014.

She is currently a Lecturer in Old Javanese Department, Faculty of Arts, Udayana University. Her research interest includes microlingistics, especially morphosyntax of Old Javanese, and local languages. Some scientific articles are already published on accredited national journals, namely; Eksistensi dan Dinamika Kosa Kata Bahasa Jawa Kuna pada Masyarakat Bali Masa Kini; Tipologi Kausatif Formal Bahasa Jawa Kuna; Medial Diathesis in Old Javanese; etc.

Dr. Erawati is a member of "Masyarakat Linguistik Indonesia" (MLI) (Indonesian Linguistic Society) and “Asosiasi Peneliti Bahasa-Bahasa Lokal” (APBL) (Association of Local Languages Researcher). 